\title{
Pemeringkatan Faktor-Faktor Keberhasilan Penerapan Teknologi Informasi Pada Tahap Operasional Dengan Analytical Hierarchy Process
}

\author{
Widjaja Djohan $^{1}$, Suryadi Winata ${ }^{2}$, Agus Kusnawan $^{3}$ \\ Universitas Katolik Indonesia Atma Jaya \\ Universitas Buddhi Dharma \\ widjaja.djohan@yahoo.com
}

\begin{abstract}
Abstrak
Faktor keberhailan dalam penerapan teknologi informasi dari perspektif praktis terdiri atas penerapan tahap implementasi dan tahap operasional. Pada tahap operasional terdapat faktorfaktor antara lain; prosedur pelaksanaan dan dokumentasi system, pelatihan, pengendalian input, pengamanan data, prosedur pemulihan data dan program serta dukungan manajemen. Riset perlu dilanjutkan lagi dengan pemeringkatan tingkat kepentingan faktor-faktor yang dimaksud dalam rangka mempercepat implementasi dalam suatu perusahaan.

Metode yang digunakan untuk menentukan faktor terpenting dari ke enam faktor adalah metode proses analisis peringkat (hierarchy analytical process). Proses analisis peringkat atau $A H P$ merupakan metode penentuan peringkat yang sering digunakan dalam pengambilan keputusan manajemen (management decision making).

Penelitian ini mengidentifikasi faktor terpenting dalam rangka mempercepat penerapan teknologi informasi dalam perspektif praktis. Sehingga harus dilakukan studi untuk mendapatkan faktor mana yang terpenting dari ke enam factor penentu keberhasilan tersebut. Berdasarkan analisis peringkat dihasilkan bahwa yang terpenting adalah faktor adanya dukungan manajemen. Artinya adanya dukungan manajemen dari tingkat yang terendah lower level atau middle level sampai dengan top level management adalah syarat mutlak berhasilnya penerapan teknologi informasi
\end{abstract}

Kata kunci: Teknologi Informasi, Faktor-faktor Penentu Tahap Operasional, dan $A H P$

\section{Pendahuluan}

Dalam situasi usaha yang sangat komprehensif dan berorientasi pada layanan konsumen saat ini, informasi merupakan penentu suksesnya suatu usaha. Teknologi yang terkait dengan informasi berkembang sangat pesat beberapa dekade yang lalu. Perusahaan yang lebih dahulu menerapkan teknologi informasi mendapatkan keunggulan bersaing dibandingkan perusahaan yang lambat dalam penerapan teknologi informasi (Sukardi, 1992).

Penerapan teknologi informasi lebih dikenal kemudian dengan istilah komputerisasi karena hampir selalu melibatkan penggunaan computer di dalam kegiatannya, merupakan kegiatan yang rumit dan melibatkan hamper seluruh departemen di dalam organisasi perusahaan. Investasi yang besar sehingga perusahaan besar saja yang mampu melakukannya secara terintegrasi dan sekali pelaksanaan (Sukardi, 1992).

Penerapan teknologi informasi dapat dibagi atas dua tahap utama, tahap implementasi dan tahap operasional. Setiap tahap menghadapi permasalahan yang berbeda satu sama lain. Dalam tahap implementasi meliputi kuatnya dukungan manajemen puncak (top management), perancangan

${ }^{1}$ Korespondensi: Widjaya Djohan. Universitas Katolik Indonesia Atma Jaya. Jl. Jend. Sudirman No. 51, Semanggi, Setia Budi, Jakarta Selatan 12930.widjaja.djohan@yahoo.com

${ }^{2}$ Korespondensi: Suryadi Winata. Universitas Buddhi Dharma. Jl. Imam Bonjol No. 41 Karawaci Ilir, Tangerang. suryadi.winata@buddhidharma.ac.id

${ }^{3}$ Korespondensi: Agus Kusnawan. Universitas Buddhi Dharma. Jl. Imam Bonjol No. 41 Karawaci Ilir, Tangerang. agus.kusnawan@buddhidharma.ac.id 
bentuk laporan yang akan dihasilkan, bentuk rancangan system yang akan diterapkan, penanganan perubahan tugas dan wewenang staf-staf yang terlibat, dan kesiapan perencanaan peralihan system. Keberhasilan dalam tahap operasional ditentukan oleh factor-faktor seperti tersedianya prosedur pelaksanaan dan dokumentasi system, pelatihan terhadap staf yang terlibat dengan system yang baru, pengendalian input, pengamanan data dari kerusakan dan akses yang tidak diperbolehkan, tersedianya prosedur untuk pemulihan data dan program (data and program recovery), serta tingkat dukungan seluruh manajemen (Sukardi, 1992).

Terinspirasi oleh hasil temuan penelitian tentang pengembangan manajemen koperasi oleh di Kabupaten Tangerang tahun 2006 yang dapat mengungkap lima (5) faktor penghambat, maka selanjutnya perlu dilakukan skala prioritas berdasarkan peringkat pengaruh faktor-faktor yang bersangkutan (Kusnawan, Winata dan Wanto, 2018). Dalam penelitian ini penentuan skala prioritas implementasi pengembangan manajemen koperasi, dilakukan dengan pemeringkatan faktor penghambat yang terpenting dengan menggunakan Analytical hierarchy process (AHP) atau proses analisis peringkat.

AHP merupakan perhitungan yang sederhana namun handal untuk pemeringkatan faktor-faktor yang dimaksud dalam rangka implementasi. $A H P$ adalah metode yang sering digunakan dalam proses pengambilan keputusan manajemen (Sudarsono, 2004).

Penentuan faktor yang paling diprioritaskan untuk memperkuat implementasi teknologi informasi dibutuhkan supaya pengembangan kecepatan informasi perusahaan dapat dipercepat. Kemudian perbaikan pada faktor yang paling penting dapat juga mempengaruhi perbaikan faktorfaktor lainnya untuk teknologi informasi di perusahaan. Sehingga berlanjut pada penciptaan keunggulan daya saing (Nugroho, 1992).

\section{Literature Review/Related Works Tahap Operasional;}

Tahap operasional lebih merupakan suatu proses yang berkesinambungan dan factor-faktor yang dibahas terus menerus relevan dengan perusahaan yang menerapkan sistem informasi dengan komputerisasi yang terintegrasi terutama (Sukardi, 1992). Tahap operasional selalu dimulai setelah tahap implementasi selesai dan sistem informasi yang baru beroperasi untuk memenuhi kebutuhan informasi perusahaan.

\section{Prosedur Pelaksanaan dan Dokumentasi Sistem;}

Suatu sistem terkomputerisasi untuk dapat beroperasi dengan lancar dan menghasilkan informasi akurat, harus ada dukungan prosedur manual yang baik. Prosedur ini seringkali tidak diperhatikan oleh pelaksana implementasi sistem dan dianggap sebagai tugas tambahan saja. Prosedur dan dokumentasi sistem seringkali hanya merupakan by product dari implementasi sistem informasi (Sukardi, 1992).

Setiap sistem komputer suatu perusahaan selalu mempunyai interface dengan sistem manual, setidaknya pada sisi input dan output (pada sistem komputer yang tidak terintegrasi). Sistem computer sendiri dapat dipandang sebagai suatu kumpulan prosedur, yang sering kali sangat rumit dan dilaksanakan secara otomatis dan konsisten. Prosedur manual pada sisi masukan dan keluaran sistem, akan membantu terlaksananya proses masukan yang konsisten dan akurat, serta menjamin distribusi keluaran sistem pada mereka yang membutuhkan informasi yang dihasilkan. Kecenderungan yang terjadi pada perkembangan teknologi menunjukkan adanya usaha untuk mengurangi proses manual dalam mengolah masukan. Penggunaan magnetic strips, bar code, scanner, magnetic ink, optical character reader, dan alat sejenis, memungkinkan proses masukan 
menjadi lebih cepat, mudah dan akurat. Walaupun demikian prosedur manual tetap diperlukan, terutama untuk menangani masalah-masalah yang bersifat contingency, seperti misalnya memperbaiki kesalahan masukan, penanganan jenis masukan yang jarang terjadi, dan sebagainya. Dokumentasi program, untuk sistem yang dikembangkan sendiri, bila dibuat dengan lengkap dan jelas, akan membantu kelancaran pemeliharaan program. Dengan dokumentasi yang baik, kesalahan-kesalahan program akan dapat ditemukan dengan lebih mudah. Cara pemasangan (installation) program juga penting untuk didokumentasikan, sehingga jika terjadi kerusakan program, pemasangan kembali program akan dapat dilakukan dengan cepat, tanpa ketergantungan kepada keberadaan sistem analis yang mengimplementasikan sistem. Parameterparameter sistem yang harus diberikan nilai tertentu hendaknya dinyatakan dengan jelas dalam dokumentasi tertentu, beserta implikasinya bila parameter tersebut tidak diberi nilai sebagaimana mestinya. Sehingga dapat disimpulkan juga bahwa dokumentasi mengurangi ketergantungan perusahaan terhadap seorang individu. Dalam hal sistem analis sudah tidak bekerja lagi di perusahaan, maka sistem akan tetap dapat beroperasi dengan baik, dan pemeliharaan sistem tidak akan tertunda-tunda (Sukardi, 1992; Sudibyo, 1992; Nugroho, 1992).

\section{Pelatihan;}

Kelancaran operasi sistem informasi sangat tergantung pada karyawan yang mampu mengoperasikannya. Untuk mengembangkan kemampuan karyawan perusahaan sendiri, maka pelatihan memegang peran penting. Di perusahaan perlu dibuatkan prosedur tertulis untuk membuat proses pelatihan berjalan lancar (Sukardi, 1992; Sudibyo, 1992) .

Pelatihan harus mencakup penjelasan terinci mengenai prosedur-prosedur baru untuk dijalankan, contoh dalam kasus penanganan sistem baru. Untuk tingkatan supervisor atau yang lebih tinggi, harus diberikan pemahaman yang merujuk pada efek sampingan yang akan timbul akibat transaksi tertentu (Sukardi, 1992).

\section{Pengendalian masukan (input);}

Pengendalian masukan mengandung peranan penting dalam mengurangi kesalahan masukan. Pengendalian masukan dapat dibantu dengan dibuatnya suatu prosedur yang jelas, pelatihan yang baik dan penggunaan teknik tertentu, seperti yang telah dibicarakan dalam pembahasan sebelumnya. Perancangan formulir masukan yang baik juga dapat membantu pengendalian input (Whitten, Bentley dan Barlow, 1989; Sukardi, 1992).

Berikut ini adalah beberapa faktor yang harus dipertimbangkan dalam perancangan formulir input:

a. Data yang sifatnya variable saja yang dimasukan di dalam formulir input. Data yang bersifat tetap, jika hendak dimasukan dalam formulir input nilainya harus telah dicetak terlebih dahulu di dalam formulir input.

b. Tidak diperkenankan menyertakan data yang dapat dihitung secara otomatis oleh sistem di dalam formulir input, kecuali data yang digunakan untuk pengujian kebenaran input misalnya batch control total.

c. Harus menggunakan kode atau singkatan untuk memudahkan pengisian formulir input.

d. Menghindari pengisian dengan tulisan tangan sedapat mungkin, misalnya dengan penggunaan pilihan. Untuk penulisan manual diusahakan menggunakan kotak-kotak untuk dimasukan ke dalam sistem.

e. Urutan data yang dimasukan harus sama dengan urutan field yang ada ditampilan input.

f. Sedapat mungkin mencantumkan instruksi cara pengisian pada setiap formulir input.

Pengendalian input juga dapat dilakukan dengan penulisan program computer yang baik: 
a. Pemeriksaan kelengkapan (completeness checks) menguji apakah seluruh field yang harus diisi telah lengkap.

b. Limit checks dan range checks, untuk menguji apakah data yang dimasukan dalam batas-batas yang valid untuk field yang bersangkutan.

c. Combination checks, menguji apakah hubungan antara nilai dari dua field adalah mempunyai hubungan yang valid.

d. Self-checking digits, teknik yang digunakan untuk mengetahui apakah data yang merupakan kunci utama telah dimasukkan dengan benar. Teknik ini menggunakan satu karakter tambahan pada kunci utama. Karakter tambahan ini ditentukan menggunakan formula, jika karakter terakhir yang dimasukan tidak cocok dengan karakter yang telah dihitung komputer, maka telah terjadi kesalahan input.

e. Picture checks, seperti yang tersedia pada bahasa $C O B O L$, Dbase.

Teknik-teknik yang dibicarakan tersebut hanya berfungsi membantu, dan tidak menentukan ketepatan input. Perlu ditekankan bahwa yang berperan penting dalah pengendalian input adalah disiplin personalia yang melakukan proses tersebut (Sukardi, 1992; Sudibyo, 1992).

\section{Pengamanan Data;}

Data dalam bentuk file komputer dapat lebih mudah rusak daripada data dalam bentuk kertas (hard copy). Data adalah harta perusahaan yang keberadaannya sangat penting untuk operasional perusahaan sehari-hari. Oleh karenanya data tersebut harus dijaga dan dilindungi.

Metode perlindungan data komputer yang dapat dilakukan antara lain adalah backup dan pencegahan virus komputer. Selain itu sebagian data ada yang bersifat rahasia atau pribadi. Akses terhadap data yang rahasia dan pribadi harus terbatas untuk orang-orang yang berhak saja., misalnya dengan menggunakan password.

Backup umumnya dilakukan dengan menggunakan harddisk karena kapasitas nya yang besar dan harganya relatif terjangkau. Untuk kepastian bahwa backup sudah dilaksanakan sesuai jadwal yang direncanakan, maka harus ada orang tertentu yang disebut system administrator. Di samping buku logistic catatan backup harus tetap digunakan untuk pemantauan secara manual.

\section{Metode Penelitian}

\section{Analytical Hierarchy Process;}

Analytical Hierarchy Process (AHP) merupakan salah satu metode pengambilan keputusan multicriteria dengan cara menentukan artikulasi preferensi awal (prior articulation of preferences). Pengambilan keputusan dalam hal ini juga merupakan pengambilan keputusan rumit karena dapat terjadi akibat dan tujuan, kriteria permasalahan atau alternative yang beragam. Kemiripan antara keputusan pilihan berdasarkan bobot dan peringkat di dalam $A H P$ dengan keputusan urutan faktor penentu keberhasilan menjadi alasan utama penggunaan $A H P$ untuk pembobotan dan pemeringkatan alternative pengaruh faktor-faktor penentu keberhasilan.

Penelitian terdahulu yang menyangkut baik profesi di bidang akuntansi, bidang sosial, bidang pendidikan dan bidang teknik sipil, pada sektor swasta dan instansi pemerintahan ada yang telah menggunakan $A H P$ sebagai metode penelitian dan pengolahan data, misalnya penggunaan $A H P$ untuk identifikasi faktor penghambat keberhasilan manajemen pada koperasi ikan hias (Kusnawan, et al., 2018).

Hasil analisis dan pembahasan penelitian terlebih dahulu menjelaskan hasil analisis peringkat (analytical hierarchy process) atau AHP. Analisis AHP ini disusun menggunakan data pernyataan peringkat narasumber bidang computer dan ahli implementasi teknologi informasi. Peringkat AHP digunakan untuk memperkuat penetapan faktor-faktor penentu keberhasilan yang terpenting. 
Terkait dengan pemikiran ini, maka metode analytical hierarchy process (AHP) dipilih sebagai metode yang tepat untuk melakukan proses hierarki analisis permasalahan pengambilan keputusan prioritas factor penentu keberhasilan implementasi teknologi informasi. Implikasi penggunaan metode $A H P$ dalam penelitian ini, adalah:

a. AHP mampu menyusun struktur hierarki dari tujuan I (pengambilan keputusan) ke tingkatan di bawahnya dan kriteria-kriteria.

b. AHP mampu menganalisis bobot sub kriteria dalam tahapan pengambilan keputusan penetapan faktor keberhasilan yang paling menentukan.

c. AHP mampu mengkuantifikasikan data kualitatif (faktor-faktor dan variabel-variabel) dengan menganalisis konsistensi jawaban (pendapat) responden (pakar) yang dituangkan dalam skala rasio 1 (satu) sampai dengan 9 (sembilan), yang dianggap cukup mewakili persepsi individu dalam memberikan perbandingan tingkat kepentingan pasangan variabel satu sama lainnya dengan perhitungan rasio konsistensi.

Instrumen penelitian disesuaikan dengan instrumen yang telah dilakukan oleh peneliti terdahulu. Kuesioner $A H P$ skala penilaian perbandingan untuk masing-masing tahap pengambilan keputusan yang menyangkut faktor penentu keberhasilan dapat dilihat pada Tabel 1 Skala Penilaian Perbandingan (Pair Wise Comparison) berikut ini:

Tabel 1. Skala Penilaian Perbandingan (Pair Wise Comparison)

\begin{tabular}{|c|c|c|}
\hline Nilai skala & Definisi & Keterangan \\
\hline 1 & $\begin{array}{l}\text { Kedua kriteria sama pentingnya } \\
\text { (Equal) }\end{array}$ & $\begin{array}{l}\text { Kedua kriteria memberikan } \\
\text { kontribusi yang sama }\end{array}$ \\
\hline 3 & $\begin{array}{l}\text { Kriteria yang satu sedikit lebih } \\
\text { penting (Moderate) }\end{array}$ & $\begin{array}{l}\text { Pengalaman dan pertimbangan } \\
\text { sedikit memihak kriteria satu } \\
\text { dibandingkan yang lainnya }\end{array}$ \\
\hline 5 & $\begin{array}{l}\text { Kriteria yang satu lebih penting } \\
\text { dibandingkan lainnya (Strong) }\end{array}$ & $\begin{array}{l}\text { Pengalaman dan penilaian sangat } \\
\text { memihak kriteria ratu } \\
\text { dibandingkan dengan yang lainnya }\end{array}$ \\
\hline 7 & $\begin{array}{l}\text { Kriteria yang jelas lebih penting } \\
\text { dibandingkan yang lainnya (very } \\
\text { strong) }\end{array}$ & $\begin{array}{l}\text { Kriteria yang satu dengan kuat } \\
\text { disukai dan dominasinya sangat } \\
\text { nyata dalam praktek }\end{array}$ \\
\hline 9 & $\begin{array}{l}\text { Krtiteria yang satu Mutlak lebih } \\
\text { penting dari yang lainnya (Extremly } \\
\text { importance) }\end{array}$ & $\begin{array}{l}\text { Satu elemen terbukti mutlak lebih } \\
\text { disukai dibandingkan dengan } \\
\text { pasangannya, pada tingkat } \\
\text { keyakinan tertinggi }\end{array}$ \\
\hline $2,4,6,8$ & $\begin{array}{l}\text { Nilai tengah/nilai antara dua elemen } \\
\text { yang berdekatan }\end{array}$ & $\begin{array}{l}\text { Diperlukan pembicaraan untuk } \\
\text { antara dua pertimbangan }\end{array}$ \\
\hline $\begin{array}{l}\text { Kebalikanny } \\
\text { a }\end{array}$ & $\mathrm{A}_{\mathrm{ij}}=1 / \mathrm{A}_{\mathrm{ij}}$ & $\begin{array}{l}\text { Bila aktivitas i memperoleh suatu } \\
\text { angka bila dibandingkan dengan } \\
\text { aktivitas } \mathrm{j} \text {, maka j memiliki nilai } \\
\text { kebalikannya bila dibandingkan } \mathrm{i}\end{array}$ \\
\hline
\end{tabular}

Sumber: (Saaty dalam Bunruamkaew 2012), disesuaikan kembali

Pengukuran variabel dalam metode $A H P$ menggunakan skala perbandingan (pair wise comparasion). Berdasarkan skala ini disusun kuesioner AHP.untuk menilai tingkat kepentingan antara dua elemen yang dibandingkan, yang diperoleh dari jawaban pakar yang diwawancara. 


\section{Analisis Data Proses Analisis Peringkat (Analytical Hierarchy Process)}

Menghitung bobot prioritas masing-masing faktor pada setiap tingkatan, dengan langkahlangkah:

a. Hasil dari setiap perbandingan berpasangan yang diperoleh dari kuesioner yang sudah dijawab oleh para pakar selanjutnya ditampilkan dalam sebuah matriks perbandingan berpasangan (pair wise comparison). Membagi jumlah masing-masing elemen pada kolom tertentu dengan nilai jumlah kolom tersebut.

b. Hasil tersebut kemudian dinormalisasi untuk mendapatkan eigen vector matrix dengan merata-ratakan jumlah baris terhadap jumlah kriteria. Perhitungan di atas menunjukkan nilai murni (vector eigen) yang merupakan bobot prioritas terhadap tujuan.

c. Uji Konsistensi Penyimpangan konsistensi dinyatakan dengan Consistency Index (CI) dengan persamaan: $\quad C I=(\max -n) /(n-1)$. Dimana max adalah eigenvalue maksimum dan $n$ adalah ukuran matriks.

AHP mengukur konsistensi menyeluruh dari berbagai pertimbangan melalui suatu rasio konsistensi. Rasio ini didapat dari perbandingan antara indeks konsistensi dengan indeks random $C R=C I / R I$. Jika $C R<0,1$ maka nilai matriks perbandingan dapat diterima/konsisten. Random Index dapat dilihat pada Tabel 2 Nilai Indeks Random $(\boldsymbol{R I})$ berikut ini.

Tabel 2. Nilai Indeks Random $(R I)$

\begin{tabular}{|l|l|l|l|l|l|l|l|l|}
\hline $\mathrm{N}$ & 1,2 & 3 & 4 & 5 & 6 & 7 & 8 & 9 \\
\hline $\mathrm{RI}$ & 0,0 & 0,58 & 0,9 & 1,12 & 1,24 & 1,32 & 1,41 & 1,45 \\
\hline
\end{tabular}

Sumber : (Saaty dalam Bunruamkaew 2012)

\section{Uji Sensitivitas $\boldsymbol{A H P}$;}

Analisis sensitivitas digunakan untuk melihat kelayakan pendapat responden pakar (Expert) yang dijadikan dasar pengambilan keputusan dengan $A H P$. Analisis sensitivitas dilakukan dengan melihat faktor atau elemen dari struktur hirarki yang paling sensitif terhadap perubahan peringkatnya untuk mengetahui kemungkinan menghasilkan perubahan alternatif. Analisis sensitivitas ini dimaksudkan untuk melihat kecenderungan perubahan suatu prioritas terhadap faktor lain yang mempengaruhinya. Uji sensitivitas dilakukan dengan simulasi pada peresentasi kenaikan/penurunan kriteria sebesar yang ditentukan oleh teori atau kesepakatan kelompok peneliti dan responden pakar (ahli).

\section{Hasil}

Implementasi teknologi informasi merupakan Implementasi komputerisasi Sistem Terpadu Pendidikan Tinggi Universitas Buddhi Dharma (UBD) Tangerang yang dimulaikan pada tahun 2017 di lingkungan kampus. Pada tahap awal dilakukan lebih dahulu di aplikasi penyusunan Beban Kerja Dosen (BKD) dan Laporan Kinerja Dosen (LKD).

Beban kerja dosen dan laporan kerja dosen dikelompokkan menjadi BKD dan LKD untuk dosen yang sudah sertifikasi dan dosen yang belum sertifikasi. Pada akhir 2017 merupakan tahap implementasi. Tahap operasional dimulai pertengahan 2018 dengan awalan dimulai dengan penyusunan BKD secara online yang dilaporkan ke Lembaga Layanan Pendidikan Tinggi Wilayah IV (d/h Kopertis wilayah IV).

Pada tahap operasional implementasi teknologi informasi dalam penyusunan BKD secara online ini Universitas Buddhi Dharma menunjuk Bapak Agus Kusnawan, SE., MM. sebagai narasumber BKD untuk dosen di Fakultas Bisnis Universitas Buddhi Dharma dan para Asesor BKD Universitas Buddhi Dharma. Keberhasilan dalam implementasi tahap operasional penyusunan dan pelaporan secara online BKD dan LKD ini telah diyakinkan dengan proses pencairan insentif sertifikasi dosen (serdos). 


\section{Analisis dan Pembahasan;}

Analisis dan pembahasan yang didasarkan beberapa fair wise comparison yang telah diperoleh dari sumber imforman yang merupakan ketua Biro Sistem Teknologi Informasi (BSTI), narasumber BKD Fakultas Bisnis (FB) UBD, Kepala bagian Pangkalan Data Pendidikan Tinggi (PD Dikti) UBD, Asesor-asesor BKD pada FB UBD dan beberapa karyawan TI senior di Universitas Buddhi Dharma Tangerang sebagai experts dengan jumlah sebanyak 10 orang.

Matriks data berdasarkan fair wise comparison dapat dilihat pada tabel 3 sampai dengan 5 berikut ini:

Tabel 3. Matriks Data Berdasarkan Expert Ranks

\begin{tabular}{llcccccc}
\hline No & Faktor-faktor & $\begin{array}{c}1 \\
\text { Pro \& } \\
\text { Dok }\end{array}$ & Pelatihan & $\begin{array}{c}\text { Peng. } \\
\text { Input }\end{array}$ & $\begin{array}{c}\text { Peng. } \\
\text { Data }\end{array}$ & $\begin{array}{c}\text { Pro. Pem. } \\
\text { Data }\end{array}$ & $\begin{array}{c}\text { DUK. } \\
\text { MJM }\end{array}$ \\
\hline $\mathbf{1}$ & Pro \& Dok & 1 & 1 & 0.5 & 2 & 1 & 0.25 \\
\hline $\mathbf{2}$ & Pelatihan & & 1 & 2 & 1 & 2 & 0.25 \\
\hline $\mathbf{3}$ & Peng. Input & & & 1 & 1 & 2 & $0 / 25$ \\
\hline $\mathbf{4}$ & Peng. Data & & & & 1 & 1 & $0 / 25$ \\
\hline $\mathbf{5}$ & Pro. Pem Data & & & & & 1 & $0 / 25$ \\
\hline $\mathbf{6}$ & DUK. MJM & & & & & 1 \\
\hline
\end{tabular}

Sumber: experts

Tabel 3 Matrik data berdasarkan expert ranks merupakan matrik yang digunakan untuk menginput data yang merupakan pendapat pakar berdasarkan fair wise comparison. Pendapat pakar yang dihimpun dalam fair wise comparison merupakan pendapat dari; ketua Biro Sistem Teknologi Informasi (BSTI), narasumber BKD Fakultas Bisnis (FB) UBD, Kepala bagian Pangkalan Data Pendidikan Tinggi (PD Dikti) UBD, Asesor-asesor BKD pada FB UBD dan beberapa karyawan TI senior di Universitas Buddhi Dharma Tangerang sebagai experts dengan jumlah sebanyak 10 orang.

Penginputan dari fair wise comparison untuk tingkat kepentingan dukungan manajemen (Duk MJM), adanya pelatihan dan pengendalian dokumen input. Dukungan manajemen dalam fair wise comparison mempunyai tingkat kepentingan empat (4) kali lebih penting daripada semua factor yang mempengaruhi suksesnya penerapan teknologi informasi, sehingga diberi nilai dua $(0,25)$ pada kotak perbandingan nilai yang berpotongan dengan factor-faktor prosedur dan dokumen (Pro \& Dok), Pelatihan, Pengendalian Input (Peng. Input), Pengendalian Data (Peng. Data), Program Pemuktahiran Data ( Pro Pem. Data).

Faktor prosedur dan dokumen juga setengah $(0,5)$ kali kurang penting daripada faktor pengendalian input. Namun sebaliknya dua (2) kali lebih penting dari pada faktor pengendalian data. Kemudian faktor pelatihan dua (2) kali lebih penting dari faktor pengendalian input dan faktor prosedur pemuktahiran data. Sedangkan faktor pengendalian input dua (2) kali lebih penting daripada faktor prosedur pemuktahiran data.

Tabel 4. Fair Wise Comparison Matriks

\begin{tabular}{llcccccc}
\hline \multirow{2}{*}{ No } & Faktor-faktor & \multicolumn{1}{c}{\begin{tabular}{c} 
Pro \& \\
\cline { 3 - 7 }
\end{tabular}} & Pelatihan & $\begin{array}{c}\text { Peng. } \\
\text { Input }\end{array}$ & $\begin{array}{c}\text { Peng. } \\
\text { Data }\end{array}$ & $\begin{array}{c}\text { Pro. Pem. } \\
\text { Data }\end{array}$ & $\begin{array}{c}\text { DUK. } \\
\text { MJM }\end{array}$ \\
\hline $\mathbf{1}$ & Pro \& Dok & 1 & 1 & 0.5 & 2 & 1 & 0.25 \\
\hline $\mathbf{2}$ & Pelatihan & 1 & 1 & 2 & 1 & 2 & 0.25 \\
\hline
\end{tabular}




\section{eCo-Buss}

\begin{tabular}{clcc|cccc}
\hline $\mathbf{3}$ & Peng. Input & 2 & 0.5 & 1 & 1 & 2 & $0 / 25$ \\
\hline $\mathbf{4}$ & Peng. Data & 0.5 & 1 & 1 & 1 & 1 & $0 / 25$ \\
\hline $\mathbf{5}$ & Pro. Pem Data & 1 & 0.5 & 0.5 & 1 & 1 & $0 / 25$ \\
\hline $\mathbf{6}$ & DUK. MJM & 4 & 4 & 4 & 4 & 4 & 1 \\
\hline & Total & 9.5 & 8 & 9 & 10 & 11 & 2.25 \\
\hline
\end{tabular}

Sumber: Experts

Tabel 4 Fair Wise Comparison Matrix merupakan matrik yang digunakan untuk membuat inverse matrix sehingga semua kotak dalam matrik terisi penuh. Pada baris ketiga faktor pengendalian input mempunyai tingkat kepentingan faktor dua (2) kali lebih penting dari faktor prosedur dan dokumen. Demikian juga setengah $(0,5)$ kali lebih penting dari faktor pelatihan, atau sebaliknya faktor pelatihan dua (2) kali lebih penting daripada faktor pengendalian input. Faktor pengendalian data setengah $(0,5)$ kali kurang penting daripada faktor prosedur dan dokumentasi. Faktor program pemulihan data adalah setengah $(0,5)$ kali kurang penting daripada faktor-faktor pelatihan dan pengendalian input. Sebaliknya faktor yang terpenting yaitu faktor dukungan manajemen mempunyai tingkat kepentinga empat (4) kali lebih penting daripada semua faktor lainnya yang mendukung proses keberhasilan implementasi teknologi informasi.

Tabel 5. Normalization and consistency Ratio Measurement

\begin{tabular}{|c|c|c|c|c|c|c|c|c|c|c|c|}
\hline \multirow[b]{2}{*}{ NO. } & \multirow[b]{2}{*}{ Faktor-faktor } & 1 & 2 & 3 & 6 & 7 & 9 & \multirow[b]{2}{*}{ TOTAL } & \multirow[b]{2}{*}{ AVERAGE } & \multirow[b]{2}{*}{$C M$} & \multirow[b]{2}{*}{ RANK } \\
\hline & & Pro \& Dok & Pelatihan & Peng. Input & Peng. Data & Pro. Pem. Data & Duk. MJM & & & & \\
\hline & Pro \& Dok & 0,1052632 & 0,125 & 0,05555556 & 0,2 & 0,090909091 & 0,1111111111 & 0,68784 & 0,11464 & 6,21082 & 4 \\
\hline 2 & Pelatihan & 0,1052632 & 0,125 & 0,22222222 & 0,1 & 0,181818182 & 0,111111111 & 0,84541 & 0,140902 & 6,35454 & 2 \\
\hline 3 & Peng. Input & 0,2105263 & 0,0625 & 0,11111111 & 0,1 & 0,181818182 & 0,111111111 & 0,77707 & 0,129511 & 6,25466 & 3 \\
\hline 4 & Peng. Data & 0,0526316 & 0,125 & 0,11111111 & 0,1 & 0,090909091 & 0,111111111 & 0,59076 & 0,09846 & 6,30692 & 5 \\
\hline 5 & Pro. Pem. Data & 0,1052632 & 0,0625 & 0,05555556 & 0,1 & 0,090909091 & 0,111111111 & 0,52534 & 0,087556 & 6,20281 & 6 \\
\hline & Duk. MJM & 0,4210526 & 0,5 & 0,44444444 & 0,4 & 0,363636364 & 0,4444444444 & 2,57358 & 0,42893 & 6,32554 & 1 \\
\hline & TOTAL & 1 & 1 & 1 & 1 & 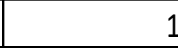 & 1 & 6 & 1 & & \\
\hline & & & & \multicolumn{4}{|c|}{ 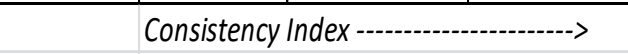 } & & $\mathrm{Cl}$ & 0,05518 & \\
\hline & & & & & \multicolumn{3}{|c|}{ Random Index from AHP --------------> } & & $R I$ & 1,24 & \\
\hline & & & & & \multicolumn{3}{|c|}{ 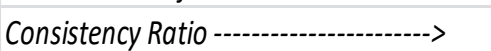 } & & $C R$ & 0,0445 & \\
\hline
\end{tabular}

Sumber: Experts

Tabel 5 Normalization and consistency Ratio Measurement dengan mendapatkan eigen vector matrix merata-ratakan dengan jumlah baris terhadap jumlah angka yang ada dalam kotak matrik atau kriteria. Kotak factor dukungan manajemen dengan angka average 0,42893 adalah merupakan nilai murni dari dua koma lima tujuh tiga lima delapan $(2,57358)$ dibagi dengan enam (6). Perhitungan di atas menunjukkan nilai murni (vector eigen) yang merupakan bobot dukungan manajemen terhadap keberhasilan implementasi teknologi industri. 
Selanjutnya masing-masing eigen vector untuk semua faktor dijumlahkan sehingga mendapat nilai total dari eigen vector. Faktor dukungan manajemen mempunyai total nilai eigen vector 6,32554 . Kemudian faktor pelatihan 6,35454 , pengendalian data 6,30692, pengendalian input 6,25466 , prosedur dan dokumentasi 6.21082 dan program pemuktahiran data 6,20281 . Nilai AVERAGE didapatkan dari membagi total eigen vector dengan total eigen vector keseluruhan yaitu lima (5). Hasilnya adalah faktor dukungan manajemen 0,42893, faktor pelatihan 0,1409, faktor pengendalian input 0,12951 , prosedur dan dokumentasi 0,11464 , pengendalian data 0,09846 dan faktor program pemuktahiran data 0,08756 .

Penjelasan tabel 5 yang terakhir adalah menghitung Consistency Measure $(C M)$ yang dapat dihitung dengan rumus atau fungsi MMULT dari faktor masing-masing dibagi dengan nilai AVERAGE masing-masing faktor. Pada tabel 5 baris lembaga dihitung dengan formula berikut: MMULT(0,105263:0,11111111;0,11464:0,42893)/0,11464 = 6,21082

Berdasarkan angka $C M$ dapat dilihat bahwa dukungan manajemen mempunyai tingkat kepentingan yang sangat tinggi sebagai tingkat kepentingan yang pertama (1) sedangkan faktor pelatihan pada urutan tingkat kepentingan ke dua (2) dengan $C M=6,32554$ dam 6,35454 dan pada urutan tingkat kepentingan ketiga juga bersama-sama adalah faktor penendalian input dengan nilai $C M$ adalah 6,25466. Lebih lanjut faktor prosedur dan dokumentasi dengan $C M$ 6,21082 , faktor pengendalian data dan faktor program pemuktahiran data dengan $C M=6.30692$ dan 6,20281

Consistensy index dihitung dengan (AVERAGE(6,21082:6,32554)-6)/5 =0,05518 Random Index dipakai tabel Random Index untuk jumlah faktor $=6$ yaitu pada angka Random Index $=$ 1,24 Rasio konsistensi (Consistency ratio) adalah Consistensy Index dibagi dengan Random Index atau $0,05518 / 1,24=0,0445$. Lebih kecil dari $(<) C R=0,1$ menunjukkan bahwa perhitungan dengan mendapatkan nilai lebih kecil dari Consistensy Ratio yang ditolelir sebesar 0,1. Artinya matrik di atas adalah konsisten dan dapat dipakai sebagai dasar pemeringkatan.

\section{Simpulan}

Berdasarkan tabel 5 Normalization and Consistency Ratio Measurement dapat dilihat bahwa faktor-faktor dukungan manajemen dan pelatihan menempati urutan pertama dan ke dua Faktor pengendalian input merupakan faktor ke tiga, factor ke empat adalah factor prosedur dan dokumentasi. Selanjutnya uruta ke lima dan enam adalah factor-faktor pengendalian data dan program pemuktahiran data.

Di dalam aspek praktik tanpa ada dukungan manajemen yang seksama implementasi program kerja yang mana pun tidak akan berhasil dengan baik. Dimulai dengan proses perencanaan dan alokasi sumber daya manusia dan anggaran biaya, yang memegang peran penting adalah adanya otorisasi manajemen. Berbagai macam risiko dalam implementasi yang mungkin timbul harus disampaikan kepada manajemen, sehingga dapat disiasati bagaimana menetralisasi dampaknya terhadap operasional perusahaan.

Untuk tersedianya sumberdaya manusia yang berkualitas sesuai dengan perkembangan kebutuhan pemanfaatan teknologi informasi dalam membantu proses pengambilan keputusan manajemen, maka sumber daya manusia yang ada harus dapat dikembangkan sehingga mampu dalam memenuhi kebutuhan implementasi teknologi informasi. Dengan demikian faktor pelatihan menjadi sangat penting untuk mendidik dan meningkatkan kemampuan kerja dengan memanfaatkan sumber daya yang sudah ada. Setelah kedua faktor terpenting ini dipenuhi dan dapat dijalankan, maka efektifitas implementasi teknologi informasi segera menjadi nyata, dan keberhasilan manajemen dalam teknologi informasi hanya tinggal menunggu waktu saja. 


\section{Implikasi:}

\section{Perkembangan Teknologi Manufaktur;}

Sebagai salah satu aspek terapan teknologi informasi yang sudah maju, maka aspek teknologi manufaktur dapat memunculkan sistem manufaktur fleksibel dalam merespon perubahan kebutuhan pasar. Pemanfaatan teknologi komputerisasi juga memungkinkan penerapan computer-aided design (CAD) dan computer-aided engineering (CAE).

Perkembangan implementasi teknologi informasi pada teknologi manufaktur dengan penerapan $C A D$ dan $C A E$ ini akan mampu memunculkan pabrik-pabrik modern yang akan mampu melakukan inovasi yang luar biasa cepatnya dan mampu menghasilkan produk-produk dengan desain yang sempurna. Komputer juga dapat mengubah tahap proses pengolahan produk dengan digunakannya computer-aided manufacturing (CAM), flexible manufacturing system (FMS) dan computer integrated system (CIM)

\section{Technology Driven Strategy;}

Technology Driven Strategy adalah cara bekerja manajemen yang menempatkan teknologi sebagai pendorong perusahaan dalam memasuki pasar. Berawal dari keterbatasan yang melekat dan implementasi teknologi yang sudah dilakukan.

Perusahaan dengan technology driven strategy seperti Amerika Serikat telah menikmati posisi persaingan yang sangat menguntungkan, sehingga dengan teknologi yang sudah dimiliki sebelumnya, negara tersebut mampu menguasai pasar dunia. Negara yang mampu melakukan perang dagang dengan Amerika Serikat harus mampu mendapat teknologi yang lebih efisien dan murah, seperti yang dilakukan oleh Negara Tiongkok

\section{Daftar Pustaka}

Bunruamkaew, Khwanruthai (D3); (2012); How to do AHP analysis in excel, Division of Spatial Information Science, Graduate School of Life and Environmental Sciences, University of Tsukuba.

Nugroho, Eko., (1992), Peran Sistem Informasi Stratejik Dalam Menciptakan Keunggulan Daya Saing, Konvensi Nasional Akuntansi ke-2, Yogyakarta

Riki, R. (2018). Implementation of Information Technology Governance Based on CoBIT Framework 5. Case Study: Bureau of Information Systems \& Technology-Buddhi Dharma University. Tech-E, 1(2), 43-50.

Simbolon, S., Peng Wi, \& S. Wibowo, (2017), Implementasi Time Driven Activity Based Costing $(T D A B C)$ Pada Budidaya Arwana di Kolam Tirtamas, Penelitian Fakultas Bisnis UBD Tangerang, Publikasi pada Konferensi Akuntansi Banten ke 1, 9 - 11 Januari, 2018

Sudarsono, D. T. E., (2004) Penerapan Analytical Hierarchy Process (AHP), Untuk Penelitian Metode Audit PDE oleh Auditor Internal, Proceedings Komputer dan Sistem Inteljen (Kommit, 2004), Universitas Gunadarma, Jakarta, ISSN 1411-6286.

Sukardi, Hardi., (1992), Isu Kritikal Dalam Penerapan Teknologi Informasi Dalam Praktis, Konvensi Nasional Akuntansi ke-2, Yogyakarta.

Sudibyo, Pladicus., (1992), Isu Kritikal Dalam Penerapan Teknologi Informasi, Konvensi Nasional Akuntansi ke-2, Yogyakarta.

Supriyono, W. W., Wardhana dan Sudaryo, (2007), Sistem Pemilihan Pejabat Struktural dengan Metode AHP. Seminar Nasional III SDM Teknologi Nuklir, Yogyakarta-ISSN 1978 - 0176.

Sutrisna dan Winata, Suryadi, (2014), Eksplorasi Bidang Akuntansi pada Budidaya Ikan Hias Air Tawar (Studi Budidaya Mas koki di Kolam Tirtamas, Desa Mekar Kondang, kecamatan Sukadiri, kabupaten Tangerang, provinsi Banten), Prosseding Kongres ISEI Surabaya, STIE Perbanas, Surabaya. 


\section{eCo-Buss}

Winata, S., (2006), Identifikasi Faktor-faktor Penghambat Pada Penerapan dan Pengembangan Manajemen Koperasi Di Kabupaten Tangerang - Banten, Jurnal Manajemen Krida Wacana $6(3)$ 